\title{
Correction to: A primary neural cell culture model to study neuron, astrocyte, and microglia interactions in neuroinflammation
}

Noah Goshi ${ }^{1}$, Rhianna K. Morgan ${ }^{2}$, Pamela J. Lein ${ }^{2}$ and Erkin Seker ${ }^{3 *}$

Correction to: Journal of Neuroinflammation (2020) 17:155 https://doi.org/10.1186/s12974-020-01819-z

Following publication of the original article [1], the authors identified a typo in one value. The $5 \mu \mathrm{g} / \mathrm{mL}$ as the LPS concentration were wrongly given as $5 \mu \mathrm{M}$ in several instances in the article. This typo does not affect any results or conclusions.

It should read as: $5 \mu \mathrm{g} / \mathrm{mL}$.

Author details

'Department of Biomedical Engineering, University of California-Davis, Davis, CA 95616, USA. ${ }^{2}$ Department of Molecular Biosciences, University of CaliforniaDavis, Davis, CA 95616, USA. ${ }^{3}$ Department of Electrical and Computer Engineering, University of California-Davis, 3177 Kemper Hall, Davis, CA 95616, USA.
Published online: 12 February 2022

\section{Reference}

1. Goshi N, Morgan RK, Lein PJ, Seker E. A primary neural cell culture model to study neuron, astrocyte, and microglia interactions in neuroinflammation. J Neuroinflamm. 2020;17:155. https://doi.org/10.1186/ s12974-020-01819-z.

\section{Publisher's Note}

Springer Nature remains neutral with regard to jurisdictional claims in published maps and institutional affiliations. to the material. If material is not included in the article's Creative Commons licence and your intended use is not permitted by statutory regulation or exceeds the permitted use, you will need to obtain permission directly from the copyright holder. To view a copy of this licence, visit http://creativecommons.org/licenses/by/4.0/. The Creative Commons Public Domain Dedication waiver (http://creativeco mmons.org/publicdomain/zero/1.0/) applies to the data made available in this article, unless otherwise stated in a credit line to the data. 